\title{
Kecernaan Pakan Sapi Perah Laktasi Akibat Modifikasi Lingkungan Kandang Di Teaching Farm Universitas Diponegoro
}

\author{
(Feed Digestibility of Dairy Lactating Cow Due to Modification of Environment on \\ Diponegoro University Teaching Farm)
}

\author{
Septiana Nugraheni', Rudy Hartanto ${ }^{2}$, Dian Wahyu Harjanti ${ }^{2}$ \\ ${ }^{1)}$ Fakultas Peternakan dan Pertanian, Universitas Diponegoro, Semarang \\ ${ }^{2)}$ Laboratorium Produksi Ternak Potong dan Perah, Fakultas Peternakan dan Pertanian \\ Universitas Diponegoro, Semarang. \\ Jalan Prof. H. Soedarto, S. H., Tembalang, Kota Semarang, Jawa Tengah 50275 \\ Telp : (024) 7460024 \\ *Corresponding email : septiananugra14@gmail.com
}

\begin{abstract}
ABSTRAK
Tujuan dari penelitian ini untuk mengetahui pengaruh modifikasi lingkungan kandang terhadap kecernaan pakan sapi perah laktasi di Teaching Farm sapi perah Fakultas Peternakan dan Pertanian Universitas Diponegoro. Materi yang digunakan adalah 8 ekor sapi perah FH periode laktasi dengan bobot badan $443,18 \pm 34,13 \mathrm{~kg}$ dan produksi susu awal $6,09 \pm 1,84$ liter/hari. Rancangan percobaan yang digunakan berupa Cross-over Design yang terbagi menjadi 2 perlakuan dengan 4 ulangan dan berlangsung dalam 2 periode selama 22 hari dengan pembagian waktu 11 hari setiap periode dengan jeda istirahat selama satu hari sebelum pergantian periode. Pengambilan data dengan metode total koleksi dilakukan pada hari ke $8-11$. Modifikasi lingkungan kandang yang diberikan meliputi penambahan kipas angin dan nozzle (T1) serta kontrol atau tanpa penambahan kipas angin dan nozzle (T0). Parameter yang diamati adalah kecernaan bahan kering (KcBK) dan kecernaan bahan organik (KcBO). Data yang diperoleh kemudian dianalisis dengan analisis ragam (ANOVA) pada taraf signifikasi $5 \%$. Berdasarkan penelitian yang dilakukan diperoleh hasil bahwa perlakuan yang diberikan dengan menambahkan kipas angin dan nozzle tidak mempengaruhi KcBK dan KcBO dengan hasil pada T0 yaitu $62,56 \pm 4,83 \%$ dan $71,56 \pm 7,11 \%$, sedangkan untuk T1 yaitu $62,89 \pm 4,42 \%$ dan $72,78 \pm 4,22 \%$. Kesimpulan yang diperoleh dari hasil penelitian adalah modifikasi lingkungan kandang yang dilakukan belum dapat meningkatkan KcBK dan KcBO.
\end{abstract}

Kata Kunci : Sapi Perah, Konsumsi, Kecernaan, Modifikasi Lingkungan

\begin{abstract}
The aim of this research was to determine the effect of dairy barn modification on the feed digestibility of dairy cow in Teaching Farm of Diponegoro University. Material used for this research were 8 dairy cows with average body weight 443,18 $\pm 34,13 \mathrm{~kg}$ and milk production 6,09 $\pm 1,84$ liter/days. Experimental design used Cross-over Design which was devided into 2 treatments with 4 replications in 2 periods for 22 days within 11 days in each period. Feed digestibility data was determined using fecess total collection on day 8 to 11 . The treatment applied to dairy barn were the installation of fan and nozzle as the cooling system (T1) and without the cooling system (TO). The paramenters observed were dry matter digestibility (DMD) and organic matter digestibility (OMD). Data were obtained then analyzed by analysis of variance (ANOVA) at significance level of $5 \%$. The result showed that addition of fan and nozzle did not gave the different result of DMD and OMD at TO is $62,56 \pm 4,83 \%$ and $71,56 \pm 7,11 \%$, whereas at $T 1$ is $62,89 \pm 4,42 \%$ and $72,78 \pm 4,22 \%$. In conclusion, the modification did not affect to the DMD and OMD.
\end{abstract}

Keywords : Dairy Cow, Consumption, Digestibility, Modification of Environment

Septiana Nugraheni', Rudy Hartanto ${ }^{2}$, Dian Wahyu Harjanti' ${ }^{2}$ Kecernaan Pakan Sapi Perah Laktasi 


\section{PENDAHULUAN}

Sapi perah Friesian Holstein $(\mathrm{FH})$ merupakan sapi yang sangat peka terhadap perubahan suhu lingkungan di sekitarnya yang apabila mengalami peningkatan dan melampaui zona nyamannya maka sapi akan mengalami cekaman panas terus menerus yang berakibat pada menurunnya produktivitas dari ternak tersebut. Faktor lingkungan yang menjadi kendala adalah iklim mikro yang mempengaruhi secara langsung terdiri dari suhu, kelembaban, radiasi sinar matahari dan kecepatan angin, sedangkan yang mempengaruhi secara tidak langsung yaitu evaporasi dan curah hujan (Sudrajad dan Adiarto, 2011). Suhu udara yang tinggi dapat meningkatkan beban panas pada ternak dan dapat mengakibatkan ternak kesulitan dalam pelepasan panas sehingga akan berpengaruh pada menurunnya konsumsi pakan dan meningkatnya konsumsi air minum untuk membantu melepaskan panas dalam tubuh ternak (Zaki, 2015).

Kecernaan pakan baik itu merupakan kecernaan bahan kering (KcBK) dan kecernaan bahan organik (KcBO) merupakan hal utama yang perlu diperhatikan dalam mengevaluasi keterbatasan nilai konsumsi ternak akibat faktor internal pakan, selain laju dan lama gerakan digesta dari rumen sebagai faktor yang berperan dalam mempengaruhi nilai konsumsi dari ternak tersebut (Kusmartono, 2015). Besar kecilnya kecernaan pakan menentukan banyak sedikitnya nutrien yang dapat dimanfaatkan untuk memenuhi kebutuhan hidup pokok, pertumbuhan ternak serta produktivitas ternak tersebut (Widya et al., 2008). Kecernaan bahan pakan dipengaruhi oleh beberapa faktor yang meliputi konsumsi pakan, associative effect, pemrosesan pakan, umur hijauan dan suhu lingkungan (Astuti et al., 2009). Palatabilitas ternak terhadap pakan merupakan faktor utama yang menjelaskan perbedaan konsumsi antara pakan ternak yang selanjutnya palatabilitas berasosiasi dengan kecernaan yang tinggi dari suatu pakan (Novianti et al., 2014).

Iklim tropis dengan suhu dan kelembaban yang relatif tinggi dapat berakibat pada proses penguapan dari dalam tubuh ternak sehingga menyebabkan ternak mengalami cekaman panas dan dapat menurunkan produktivitas dari ternak tersebut (Yani dan Purwanto, 2006). Kebutuhan sistem tubuh yang meningkat untuk mengurangi beban panas yang berlebih, mengurangi laju metabolik serta penyusutan pada konsumsi (Sudrajad dan Adiarto, 2011). Ketika ternak tidak mampu melepas panas dalam tubuh melalui konduksi, konveksi maupun radiasi, mereka akan cenderung mengurangi konsumsi bahan kering untuk menurunkan produksi panas tubuh (Rianto et al., 2005). Suhu udara berpengaruh langsung terhadap nafsu makan ternak dan jumlah pakan yang dikonsumsi dan penurunan metabolisme (Yani dan Purwanto, 2006).

Modifikasi iklim mikro di lingkungan peternakan diharapkan mampu menurunkan cekaman panas sehingga produktivitas dapat meningkat (Anggraeni dan Mariana, 2016). Modifikasi lingkungan merupakan sebuah usaha yang dilakukan dalam manajemen ternak sapi perah $\mathrm{FH}$ dalam mengurangi cekaman panas (Yani dan Purwanto, 2006). Modifikasi lingkungan dapat dilakukan dengan pemberian naungan, kandang dengan perbesaran pada lubang angin atau ventilasi pasif serta penggunaan kipas angin dan alat penyiram dapat meningkatkan pelepasan panas berlebih dalam tubuh, menurunkan suhu tubuh dan meningkatkan konsumsi bahan kering (West, 2003). Penambahan kipas angin dan nozzle di lingkungan dalam kandang dilakukan dengan tujuan agar dapat menurunkan suhu dan kelembaban lingkungan dalam kandang sehingga diharapkan dapat 
mempengaruhi konsumsi serta daya cerna ternak terhadap pakan.

Tujuan dari penelitian ini adalah untuk mengetahui adanya pengaruh dari lingkungan yang dimodifikasi sehingga mendekati zona nyaman ternak terhadap kecernaan pakan pada sapi perah $\mathrm{FH}$.

\section{MATERI DAN METODE}

Penelitian dilaksanakan pada tanggal 5 September - 27 September 2018 di Teaching Farm Sapi Perah Fakultas Peternakan dan Pertanian Universitas Diponegoro, Semarang

\section{Materi}

Materi yang digunakan adalah 8 ekor sapi perah $\mathrm{FH}$ periode laktasi di Teaching Farm FPP Undip dengan bobot badan $443,18 \pm 34,13 \mathrm{~kg}$ dan produksi susu awal 6,09 $\pm 1,84$ liter. Pakan basal yang diberikan berupa jerami dan konsentrat komersial. Alat yang diginakan berupa 4 buah kiipas angin dan 1 set nozzle dengan 4 titik semprot.

\section{Rancangan Penelitian}

Rancangan yang digunakan dalam penelitian adalah rancangan Cross-over Design yang terdiri atas 2 perlakuan dengan 4 ulangan, yang berlangsung dalam 2 periode dengan masing-masing periode berlangsung selama 11 hari serta diberi waktu istrirahat selama satu hari sebelum periode 2 dilaksanakan. Perlakuan yang dicobakan berupa modifikasi lingkungan kandang yaitu : T0 = kelompok kontrol atau tanpa penambahan kipas angin dan nozzle dan $\mathrm{T} 1=$ kelompok dengan penambahan kipas angin dan nozzle.

\section{Perlakuan dan Pengambilan Data}

Pada setiap periode, selama tahap perlakuan (11 hari) dilakukan pengecekan suhu dan kelembaban di luar dan dalam kandang, melakukan pemberian pakan berupa jerami dan konsentrat, menimbang pemberian pakan dan sisa pakan. Kemudian di hari ke $8-11$ dilakukan pengambilan data dengan metode total koleksi feses, pengambilan sampel pakan dan sisa pakan yang kemudian dilanjutkan dengan analisis bahan kering dan bahan organik terhadap sampel feses dan pakan yang telah diambil. Feses yang sudah dikering udarakan kemudian dihomogenkan per sapi dan dimasukkan ke dalam kantong plastik dan diberi label untuk selanjutnya dilakukan analisis bahan kering dan bahan organik.

Berdasarkan hasil yang diperoleh kemudian dihitung kecernaan pakan dengan rumus perhitungan sebagai berikut:

$$
\begin{aligned}
& \operatorname{KcBK}(\%)=\frac{\text { Konsumsi BK-BK Feses }}{\text { Konsumsi BK }} \times 100 \% \\
& \operatorname{KcBO}(\%)=\frac{\text { Konsumsi BO-BO Feses }}{\text { Konsumsi BO }} \times 100 \%
\end{aligned}
$$

\section{Analisis Data}

Data yang diperoleh kemudian dianalisis dengan menggunakan ANOVA dengan uji taraf $5 \%$ untuk mengetahui pengaruh dari pemberian perlakuan.

\section{HASIL DAN PEMBAHASAN}

Berdasarkan penelitian yang telah dilakukan mengenai modifikasi lingkungan, telah diperoleh hasil rataan $\mathrm{KcBK}$ dan KcBO pakan sebagai berikut. 
Tabel 1. Kecernaan Bahan Kering dan Bahan Organik Akibat Modifikasi Lingkungan

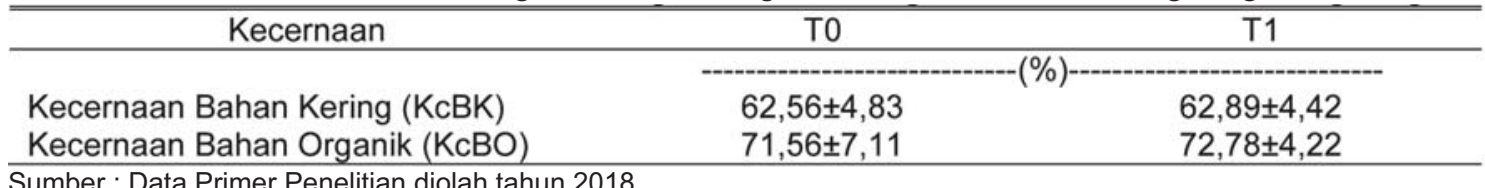

\section{Kecernaan Bahan Kering (KcBK)}

Berdasarkan data pada Tabel 1. dapat diketahui bahwa nilai rataan KcBK pakan yang diperoleh dari T0 $62,56 \pm 4,83 \%$ dan T1 62,89 $\pm 4,42 \%$. Akan tetapi dari data yang diperoleh menunjukkan bahwa modifikasi lingkungan kandang belum mampu memberikan pengaruh yang nyata terhadap peningkatan KcBK pakan. Nilai KcBK yang diperoleh berada pada kisaran NRC (2001) yaitu $52-75 \%$ untuk sapi perah. Hasil yang diperoleh sejalan dengan Novianti et al. (2014) yang menyatakan bahwa nilai KcBK pada sapi perah dengan pakan yang diberikan berupa pakan basal rumput gajah dengan ukuran potongan yang berbeda dan konsentrat berada pada kisaran $62,73 \%$. Besar kecilnya nilai KcBK memiliki kaitan erat dengan jenis dan jumlah pakan yang dikonsumsi. Hal ini diperkuat dengan pernyataan Paramita et al. (2008) yang menyatakan bahwa beberapa faktor meliputi perlakuan terhadap bahan pakan, jenis ternak serta jumlah pakan dikonsumsi yang dapat mempengaruhi nilai kecernaan terhadap pakan. Hal tersebut sejalan dengan data kelompok penelitian yang menyatakan bahwa nilai konsumsi bahan kering (BK) akibat perlakuan kipas angin dan nozzle tidak menunjukkan perubahan yang signifikan yaitu T0 sebesar $20,82 \pm 1,41 \mathrm{~kg} / \mathrm{ekor} / \mathrm{hari}$ dan untuk T1 sebesar 20,86 $\pm 1,76$ $\mathrm{kg} / \mathrm{ekor} / \mathrm{hari}$. Semua sapi mendapatkan jenis pakan yang sama dan ketika konsumsi BK yang relatif sama menyebabkan waktu tinggal pakan dalam rumen yang relatif sama sehingga kecernaan pakan yang diperoleh tidak berbeda nyata. Nuswantara et al. (2005) menyatakan bahwa apabila waktu tinggal pakan yang relatif singkat akan memberikan waktu singkat terhadap mikrobia rumen dalam mencerna pakan, tetapi waktu yang relatif singkat memungkinkan pakan akan lebih cepat meninggalkan rumen sehingga konsumsi pakan akan meningkat.

Salah satu faktor lain yang mempengaruhi tidak adanya perubahan signifikan pada KcBK adalah kondisi fisiologis lingkungan kandang. Hasil fisiologis lingkungan yang diperoleh Kartiko et al. (2019) menunjukkan suhu dan kelembaban untuk T0 yaitu $31,41 \pm 0,11^{\circ} \mathrm{C}$ dan $73,14 \pm 0,07 \%$ serta untuk T1 yaitu $30,49 \pm 0,06^{\circ} \mathrm{C}$ dan $73,41 \pm 0,11 \%$. Dari hasil yang diperoleh dapat diketahui bahwa penambahan nozzle dan kipas angin di dalam kandang mampu memberikan perubahan terhadap suhu sebesar $1^{\circ} \mathrm{C}$. Perubahan suhu yang tidak sejalan dengan KcBK diduga karena walaupun suhu pada T1 lebih rendah jika dibandingkan TO, namun suhu di dalam kandang masih tergolong tinggi sehingga ternak masih mengalami cekaman panas dan belum mampu meningkatkan produktivitasnya. Yani dan Purwanto (2006) menyatakan bahwa suhu lingkungan yang ideal untuk sapi perah pada daerah tropis seperti Indonesia yaitu pada kisaran angka $23-28^{\circ} \mathrm{C}$.

\section{Kecernaan Bahan Organik (KcBO)}

Berdasarkan data pada Tabel 1. dapat diketahui bahwa nilai rataan $\mathrm{KcBO}$ pakan yang diperoleh dari T0 $71,56 \pm 7,11 \%$ dan T1 $72,78 \pm 4,22 \%$. Akan tetapi dari data yang diperoleh menunjukkan bahwa modifikasi lingkungan kandang belum mampu memberikan pengaruh yang nyata terhadap peningkatan KcBO pakan. 
Nilai KcBO yang diperoleh tergolong baik karena semakin tinggi nilai kecernaan maka semakin banyak nutrisi yang terserap. Hasil yang diperoleh lebih tinggi dari Novianti et al. (2014) menyatakan bahwa nilai KcBO pada sapi perah dengan pakan berupa rumput gajah dengan potongan berbeda dan konsentrat adalah sekitar $64,28 \%$. KcBK dan $\mathrm{KcBO}$ akan selalu berbanding lurus karena bahan organik merupakan bagian dari bahan kering sehingga hasilnya akan cenderung mengikuti hasil dari bahan kering. Hal ini sesuai dengan pendapat Setiyaningsih et al. (2012) yang menyatakan bahwa KcBK dan KcBO pakan akan saling berbanding lurus dikarenakan bahan organik yang merupakan salah satu bagian dari bahan kering sehingga besar kecilnya kecernaan bahan kering yang diperoleh akan berpengaruh terhadap besar kecilnya kecernaan bahan organik.

$\mathrm{KcBO}$ yang tidak mengalami perubahan yang signifikan dari T0 dan T1 diduga karena nilai Temperature Humidity Index (THI) yang diperoleh masih tinggi sehingga ternak masih belum berada di zona nyaman dan mengalami cekaman panas. Berdasarkan data kelompok penelitian menunjukkan bahwa THI yang diperoleh mengalami penurunan yang signifikan yaitu dari T0 sebesar $88,11 \pm 0,022$ dan T1 sebesar $86,48 \pm 0,103$. Namun hasil THI yang diperoleh masih berada jauh diatas batas kenyamanan ternak karena nilai $\mathrm{THI}$ diatas 72 sehingga belum mampu meningkatkan KcBO secara signifikan. Novianti et al. (2013) menyatakan bahwa batas nyaman ternak adalah ketika nilai THI berada dibawah 72 dan bila melebihi batas ambang akan menyebabkan cekaman. Perubahan nilai kecernaan yang tidak signifikan bisa disebabkan karena ternak masih berada pada keadaan tidak nyaman sehingga belum mampu melakukan proses metabolisme dengan baik. Qisthon dan Widodo (2015) menyatakan bahwa ternak yang mengalami cekaman panas mengalami alih fungsi energi metabolis dari pakan untuk pertumbuhan dan produksi menjadi energi untuk termoregulasi.

\section{KESIMPULAN}

Berdasarkan hasil dan pembahasan dapat disimpulkan bahwa modifikasi lingkungan kandang dengan menggunakan kipas angin dan nozzle belum dapat meningkatkan KcBK dan $\mathrm{KcBO}$ pakan.

\section{DAFTAR PUSTAKA}

Anggraeni, A dan E. Mariana. 2016. Evaluasi aspek teknis pemeliharaan sapi perah menuju good dairy farming practices pada Peternakan Sapi Perah Rakyat Pondok Rangon. J. Agripet. 16 (2): 90-96.

Astuti, A., A. Ali dan P.S.B. Subur. 2009. Pengaruh penggunaan high quality feed supplement terhadap konsumsi dan kecernaan nutrien sapi perah awal laktasi. Buletin Peternakan. 33 (2): $81-87$.

Kartiko, M. A, P. Sambodho dan D. W. Harjanti. 2019. Respon fisiologis sapi laktasi akibat modifikasi lingkungan kandang. J. Agromedia. 37 (2).

Kusmartono. 2015. Potensi Alam Tropik dan Pertumbuhan Tanaman dan Ternak. UB Press, Malang.

NRC. 2001. Nutrient Requirements of Dairy Cattle. 7th revised edition. Washington DC : Natl. Acad. Sci. 
Novianti, J., B. P. Purwanto dan A. Atabany. 2013. Respon fisiologis dan produksi susu sapi perah $\mathrm{FH}$ pada pemberian rumput gajah (Pennisetum purpureum) dengan ukuran pemotongan yang berbeda. J. Ilmu Produksi dan Teknologi Hasil Peternakan. 1 (3): 138-146.

Novianti, J., B. P. Purwanto dan A. Atabany. 2014. Efisiensi produksi susu dan kecernaan rumput gajah (Penissetum purpureum) pada sapi perah $\mathrm{FH}$ dengan pemberian ukuran potongan yang berbeda. J. IImu Produksi dan Teknologi Hasil Peternakan. 2 (1): $224-230$.

Nuswantara, L. K., M. Soejono., R. Utomo dan B. P. Widyobroto. 2005. Kecernaan nutrien ransum prekursor nitrogen dan energi tinggi pada sapi perah yang diberikan pakan basal jerami padi. J. Indonesian Tropical of Animal and Agriculture. 30 (3) : $172-178$.

Paramita, W. L., W. E. Susanto, dan A. B. Yulianto. 2008. Konsumsi dan kecernaan bahan kering dan bahan organik dalam haylase pakan lengkap ternak sapi peranakan ongole. Media Kedokteran Hewan 24: 59-62.

Qisthon, A. dan Y. Widodo. 2015. Pengaruh peningkatan rasio konsentrat dalam ransum kambing peranakan Ettawah di lingkungan panas alami terhadap konsumsi ransum, respon fisiologis dan pertumbuhan. J. Zootek. 35 (2): 351 - 360.
Rianto, E., C. J. Thwaites dan J. V. Nolan. 2005. Pengaruh suhu lingkungan dan ketersediaan air minum terhadap kecernaan pakan, produksi nitrogen mikroba rumen dan kondisi rumen pada domba. Buletin Peternakan. 29 (1): 10 18.

Setiyaningsih, K.D., M. Christiyanto dan Sutarno. 2012. Kecernaan bahan kering dan bahan organik secara in vitro hijauan Desmodium cinereum pada berbagai dosis pupuk organik cair dan jarak tanam. J. Animal Agriculture. 1 (2): $51-63$.

Sudrajad, P. dan Adiarto. 2011. Pengaruh Stress terhadap Performa Produksi Susu Sapi Friesian Holstein di Balai Besar Pembibitan Ternak Unggul Sapi Perah Baturraden. Prosiding Seminar Nasional Teknologi Peternakan Dan Veteriner. Pusat Penelitian dan Pengembangan Peternakan, Bogor. 7-8 Juni 2011. Hal 341-346.

West, J. W. 2003. Effects of heat-stress on production in dairy cattle. J. Dairy Science. 86 (6): 2131-2144.

Widya, P. L., W. E. Susanto dan A. B. Yulianto. 2008. Konsumsi dan kecernaan bahan kering dan bahan organik dalam haylase pakan lengkap ternak sapi Peranakan Ongole. Media Kedokteran Hewan. 24 (1): 59 62. 
Yani, A., dan B.P. Purwanto. 2006. Pengaruh iklim mikro terhadap respons fisiologis sapi peranakan fries holland dan modifikasi lingkungan untuk meningkatkan produktivitasnya (ulasan). Media Peternakan. 29 (1) :35-46.

Zaki, M. 2015. Pengaruh Lingkungan terhadap Respon Termoregulasi dan Produktivitas Sapi Friesien Holstein di Kampar dan Dumai. Sekolah Pascasarjana Institut Pertanian Bogor. (Thesis). 